\title{
Dissemination of Annual Report Information on the Internet by South African Companies
}

Filistea Naudé

Gold Fields Library and Information Centre, Technikon SA

Adeline du Toit

Department of Information Studies, Rand Afrikaans University

\section{ABSTRACT}

The Internet is a cost-effective and efficient way of distributing information to all stakeholders in a transparent, globalised business environment. The aim of this study was to determine the current state and level of adoption of the Internet as a delivery and communication mechanism for disseminating online/digital annual reports in the largest listed companies in South Africa. The population selected for the survey was the 2001 Financial Mail top 300 (SA Giants) companies. The research was conducted by analysing the corporate websites of the selected companies, to establish the existence of a corporate website and whether the full annual report was available electronically. The study also investigated the relationship between digital annual reports and company characteristics. The investigation revealed that those companies with websites and digital annual reports are profitable companies.

JEL M37, M19, L86

\section{INTRODUCTION}

The rapid expansion of the Internet and the World Wide Web (WWW) has made it imperative for companies to adopt the Internet as a medium of business communication. The Internet is used as a new, efficient and effective method of distributing information to all stakeholders. Internet technology ensures instant and voluminous availability of information at low cost, thereby facilitating much broader and easier dissemination of information. The Web is a cheaper, faster and more convenient replacement for fax, telephone and postal communication with all the corporate stakeholders. Corporate websites are now being integrated into the overall business strategy because they are seen as an interface between target markets and the company. 
Stakeholders demand that they have the widest possible instantaneous access to corporate information and regulators are pressuring for more openness, speed and equality of information. Stakeholders feel they have a right to be informed and empowered and require direct, immediate access to relevant, reliable, comparable, timely and well organized, detailed and specific information about corporate operations and performance.

The objective of this article is to establish whether South African companies are making optimal use of the Internet as a method of disseminating and disclosing annual report information to stakeholders. The aim of the study was to determine the extent to which companies have adopted the Internet as a medium for publishing annual reports.

\section{FUNCTIONS OF ANNUAL REPORTS}

\subsection{Decision-making tool}

Annual reports are the most effective tool for assisting investors in making value investments in the market place (Rhein, 2000: 73). Annual reports contain a wealth of data to aid investors in determining measures for both corporate value and risk. They are used to evaluate the financial situation of corporations. Annual reports provide valuable insight into management philosophy as well as a sense of what the company is about. Financial reporting information in annual reports is classified and summarised making it decision-useful. Financial analysts often calculate representative ratios based on accounting data in annual reports and recommend that clients buy, hold or sell shares in companies.

\subsection{Corporate information source}

Annual reports are the most important source of corporate information and the first source consulted by stakeholders when searching for information. They are usually the starting point for any company research. Annual reports provide detailed financial information about companies in a standardised format. This enables easy comparison of companies and the effortless location of specific information. The standards to which annual report information must adhere are nationally defined and enforced by law.

Annual reports brief shareholders on key financial news relating to companies. They further provide an abundance of valuable information that enables investors to better understand the companies being investigated. Catrakilis (1993) conducted research to determine the information sources available and usefulness of information contained in annual reports for portfolio managers of 
large institutional shareholders when making investment decisions in South Africa. The perceptions of users about the usefulness and importance of annual reports were identified. Annual reports were found to be a widely used source of information and were identified as one of the five most important sources of information (Catrakilis, 1993: 42).

Epstein (1991) conducted a study among shareholders in the United States to determine which sections of annual reports draw the most attention. The biggest increase in readership interest was in the cash flow statement and balance sheet. Although the income statement is still the most read item in annual reports, the balance sheet comes a close second, with the cash flow statement third.

Research conducted in South Africa by Myburgh (2001: 54) indicates that the income statement is the most important section of the annual report. The balance sheet, cash flow statement and chairman's report are also ranked as very important.

The 1999 Association for Investment Management and Research (AIMR) Corporate Disclosure survey identified attitudes toward and perceptions of information sources that are the most important when analysing companies. Individuals who regularly observe publicly traded companies and work as analysts or portfolio managers were asked to participate. Three respondents out of four regarded conversations with company executives (CEO, CFO or chairperson) or annual reports as the most important sources of financial or corporate information. A total of 74 per cent of respondents rated spoken dialogue with company executives as extremely important and 71 per cent rated annual reports as extremely important (AIMR, 2000).

The corporate annual report achieved the highest score (91 per cent) for overall credibility in a survey of investment information sources conducted by the Public Relations Society of America (2000). Investors rated the annual report as the most believable source of investment information because it is governed by legal and regulatory rules requiring full disclosure to shareholders.

\subsection{Communication tool}

Effective communication with a company's shareholders and other stakeholders is a vital constituent of good governance. It is essential that interested parties be given a clear and balanced view of a company's performance (ICAEW).

Annual reports are part of the complex communication network in capital markets. This is especially true with regard to the communication between companies and other capital market participants such as investors and analysts. 
The company should communicate effectively with shareholders on issues of major strategic importance that may affect corporate performance. If not, shareholders are unable to make knowledgeable judgements on the quality of executive decisions and their long-term investment implications.

An annual report provides a means for the enterprise to communicate past actions of the company, the results of those past actions and the intended future actions of the company (Crowther, 2000: 1839).

\subsection{Marketing tool}

An annual report is part of the corporate communication strategy that pursues strategic objectives, such as strengthening of corporate image or brand. Annual reports can be useful in recruiting employees and introducing the company to new or potential customers. Prospective employees can research potential employers by studying annual reports. Annual reports are sophisticated marketing instruments for communicating the personality and philosophy of firms to readers (Stanton \& Stanton, 2001: 3).

An annual report should educate investors and project a positive image for the company. A company relies on its annual report to act as a corporate spokesperson for projecting its persona and vision (Rhein, 2000: 74).

An annual report is a practical vehicle for building confidence, selling products and increasing investor favour. Over the past 25 years the annual report has changed from a plain statement to an increasingly glossy product containing maps, charts and pictures in a multi-coloured production designed which has mass appeal (Crowther, 2000843).

The annual report should put a face and voice to a company for investors, customers and employees. A well-designed annual report should convey confidence, creativity and leadership (DeDonato \& Traver, 2000). It needs to be consistent with other communications, advertising, marketing and promotions materials.

An annual report has a captive audience. It is a historical document that needs to last an entire year. Investors and financial analysts often keep annual reports for many years, using them to determine the value of companies. Annual reports expose and reflect the soul of a company, not only its financial performance (Keenan, 2001: 54). 


\subsection{Competitive tool}

Companies operate in a global market and must compete with the best companies in the world for capital and resources. Competitiveness requires companies to be proactive, focused, open and informed. The ability to hold a dialogue with a company is a feature of competitiveness and access to information is a good indicator of confidence (ICAEW: 12).

\subsection{Investor-relations tool}

Information is the lifeblood of the investment process. The primary objective of investor relations is to provide timely information needed by investors, analysts, media and other interested groups, in order to make investment decisions. This includes the current operating results and performance of the company, past performance, financial health, company objectives and future strategy and outlook (AIMR, 2001). An annual report is one of the most important sources of information for investor relations. It is one of the tools available to investors that helps them build a better understanding of a company.

Enterprises can enhance corporate transparency through the use of electronic communications media such as the Internet, resulting in faster and more frequent disclosure. The use of electronic media should be encouraged to ensure that investor information is more accessible, accurate and timely. Websites should be proactive and have an Internet-centric approach to investor relations.

\subsection{Disclosure tool}

An annual report is an important disclosure document. Developments in information technology are leading companies to disclose business information on the Internet via company websites. There are no rules governing disclosure on the Internet.

Disclosure can be:

- Official or unofficial. Disclosure can be take place by means of official documents such as annual reports or it can take the form of private disclosures in meetings with investors.

- Mandatory or voluntary. Companies are required by law to disclose certain information in annual reports to shareholders. This is known as statutory, compulsory or mandatory company disclosure. Voluntary disclosure describes disclosures that fall primarily outside the financial statements. Laws and regulations do not stipulate voluntary disclosure. Voluntary 
disclosure should cover good news as well as disappointments (FASB, 2001).

- Financial or non-financial. Disclosure can be financial (e.g. turnover) or non-financial (such as number of employees).

- Quantitative or qualitative. Disclosure can be quantitative (expressed in numbers) or qualitative (description of strategy).

- Graphical or narrative. Disclosure can be in the form of writing, graphs or pictures (Marston \& Leow, 1998).

\section{CURRENT PROBLEMS WITH AND SHORTCOMINGS OF ANNUAL REPORTS}

Changes to corporate annual reports are being driven by globalisation, new technology and the increased notion of accountability of enterprises (ICAEW: 2).

\subsection{Limitations of printed hard copy annual reports}

- Once final annual reports are produced, they are difficult to modify or update.

- Printed copies are costly to produce and slow to distribute via postal systems. The delay in the production of printed reports is much longer compared to digital formats.

- It is difficult to access printed copies compared to digital formats. With printed copies, annual reports are only available on request via telephone, post or fax.

- They are available in linear presentation format only.

- It is difficult to do a comparison of companies. Users have to re-enter data into their own computer systems before they can manipulate it. They also have to maintain historical data for trend analysis. This is costly and ineffective. Current and historical data should be available on the company website in a format that can be exported for manipulation.

- Printed hard copies are costly duplications, especially if the data is already in electronic format on the Web.

- Users of hard copy annual reports are non-interactive, passive and being treated as a homogeneous group. Users should be able to communicate information needs to companies and provide feedback on the information received (Xiao, 1996). The Internet is the perfect medium for this purpose. 


\subsection{Demands for greater transparency}

There is a demand from stakeholders for greater transparency in annual reports. Traditionally companies have published as little information as possible, thereby preventing rival companies from gaining access to any competitive information. In contrast, transparency builds loyalty among shareholders. Corporate websites can create a respected, valued communication channel and strengthen relationships with investors (Conosco, 1999: 24). When more information is available to investors, it reduces their perception of risk and results in increased shareholder loyalty.

\subsection{Demands for greater disclosure}

A study conducted by the FASB (2001: 35) indicated that expanded disclosure of meaningful business information increases transparency and provides benefits to companies, investors and the general economy. Companies should be as proactive as possible in opening up communications. That means taking every opportunity to explain exactly how the business operates and what is happening in the company and in the industry. An increase in voluntary disclosure of business information will reduce investors' risk of making poor investment decisions. The economy benefits from the more effective allocation of investment capital, the investment effect of a lower cost of capital and more liquid capital markets. Companies benefit from a lower average cost of capital. A company's cost of capital includes a risk premium resulting from investors' uncertainty about the adequacy of the information available about the company. Increased transparency reduces that uncertainty premium.

\subsection{Demands for greater accountability}

Companies are under increasing pressure to demonstrate openness, transparency and responsibility in all activities. Markets are demanding more forwardlooking information on expected future growth, earnings potential and critical success factors (Conosco, 1999: 14).

\subsection{Demand for broader performance measurements}

Companies must increase and include information in those areas of key importance to stakeholders. Stakeholders need information such as corporate strategy, market share and market position, performance against objectives, etc. Companies should publicly articulate corporate strategy and explain to investors how each part of the business is developing in relation to past objectives or to external factors such as competitive position. The annual report should be a single, core document, published and available on the Internet, supplemented by 
detailed reports. It must improve the interpretation of performance, prospects and valuation of the company and give stakeholders a clear picture of the company's progress (Sutcliffe, 1998: 81). A recent survey by KPMG (SA firms show low disclosure levels, 2002) indicates that in South Africa, only 1 per cent of the top 100 companies produce separate and detailed reports on social, environmental or economic performance.

\subsection{Selective disclosure}

Internationally there is regulatory pressure for equal disclosure. In the USA, there has been a perception of unfair access to information by analysts and selected investors. As a result, the US Securities and Exchange Commission (SEC) has imposed additional measures on companies that make selective disclosures, with the publication of the "Fair Disclosure" regulations, which became effective from 23 October 2000. The idea behind the regulations is to encourage companies to make all information available to everybody. Fair disclosure means that institutional investors cannot be treated any differently to individual investors. The regulations effectively bar companies from disclosing material information selectively to some investors and not to others (Arthur Andersen, 2001: 8).

Although the same regulatory pressure does not currently exist in South Africa, companies would benefit from releasing price-sensitive information to the public at the same time as to analysts and institutional shareholders. The focus of information flow and disclosure should cover issues important to all investors, not just those with the largest shareholding. Improvements in accountability and responsiveness to informed shareholders must be made through public disclosure-based mechanisms, not in meetings with major institutional shareholders which take place behind closed doors (AIMR, 2000).

\subsection{Increased investor sophistication}

Growth in online trading is fuelling the demand for Web-ready annual reports. The Internet is making corporate information much more accessible to external audiences. This has resulted in a growth in equity culture and online share trading as a worldwide phenomenon. These investment tools were previously restricted to professional investment analysts. This has resulted in a growth in equity culture and online share trading as a worldwide phenomenon. In a survey conducted by the Public Relations Society of America (2000), respondents identified websites as the source they consulted most readily in formulating investment decisions. The Web is becoming the first medium of choice for finding investment information. 


\subsection{Globalisation}

In a globalised business environment, logistics are becoming more complex, especially the printing and delivering of annual reports. A global audience requires annual reports in two or more languages as well as suited to the reporting requirements, currencies and disciplines of multiple countries. The Internet and corporate websites enable companies to react faster to global events and provide a more in-depth, improved service to stakeholders around the globe.

\subsection{Closer contact between companies and stakeholders}

The Internet has changed the information architecture of society. The corporate landscape has been redefined and the power relationship between the company and individual has altered. Technology is forcing companies to review how they interact with their customers and potential shareholders. Companies are increasingly communicating with faceless, global, virtual communities. Investors operate globally and are very demanding. E-mail enables companies to deliver news and data quickly and efficiently to markets and to structure and customise information according to individual needs (Spaul \& Green, 1997). The Internet allows companies to gain greater control over the publication and distribution of information, creating a direct channel to core audiences and thus bypassing intermediaries.

\subsection{Increasing cost}

Estimations show that 30 per cent of the average FT-SE 350 company's investment relations budget is spent on printing and distributing annual reports. Owing to globalisation, companies are expected to disseminate annual reports to a larger number of and more geographically dispersed group of shareholders. The budget for annual reports will keep increasing. The challenge is to find ways of disseminating information fairly and on time, thus satisfying the increasing number of information-hungry investors, while keeping cost down (Conosco, 1999: 19). The Internet can be used to publish annual reports more effectively and cheaply than conventional publishing.

\section{ANNUAL REPORTS ON THE WEB IN SOUTH AFRICA}

\subsection{Methodology}

In order to ascertain how many companies in South Africa are disseminating full annual reports via the Web, research was conducted by analysing the corporate websites of selected companies. The purpose of the survey was to establish 
whether a corporate website existed and, if so, whether a full annual report was available in electronic format.

The population selected for the survey is comprised of the companies listed in the most recent version of the Financial Mail top 300 (SA Giants) companies. The list is based on total assets as published in the Financial Mail Special Survey: Top Companies, 29 June 2001. The SA Giants were selected because these companies represent the biggest and most important players in the South Africa Economy. In addition they were selected as a population because in large enterprises, the cost of collecting and disseminating electronic information is usually smaller. Bigger companies are more likely to disclose (Ernst \& Young, 2000: 15) and disseminate their annual reports on the Internet. JSE listed companies were selected, because listed firms are subject to more stringent disclosure regulations and therefore disclose more extensively (Crosoer, 2000 and Raffournier, 1995: 263). The study also investigated whether company variables such as profitability and industry type influence the extent to which companies publish annual reports on the Internet.

Profitability was selected as a variable because previous research indicates that from a sample of listed South African companies, relatively poor performers are likely to disclose relatively more voluntary information than strong performers (Crosoer, 2000). Internet Explorer (version 6.0) browser software was used to carry out the research. The Internet search was conducted during May 2002. The site search engine and site map were used to locate annual reports on corporate websites. The data collected was on visible information as presented on the website. The information found in downloadable files was not evaluated.

\subsection{Findings}

The annual reports of 260 (86.7 per cent of the sample) companies were analysed, after taking into account the fact that 37 (12.3 per cent) companies from the original sample were no longer listed on the stock exchange. In three cases (1 per cent), the corporate website was not available or the servers were down, which resulted in failed access.

The sample was surveyed to establish whether the companies had a website or a home page. Results indicated that 227 companies (75.6 per cent) had a website. Of the surveyed companies, 31 (10.3 per cent) had no website. Only two companies had a website that was under construction ( 0.8 per cent).

The websites were analysed to investigate how many companies had detailed electronic annual reports available on the Internet. Results indicated that 179 (59.6 per cent) companies had full digital annual reports on the Internet and 48 
(16 per cent) companies with websites, had no digital annual reports on the Internet (see Table 1).

Table 1 Top South African companies with full annual reports on the Internet in May 2002

\begin{tabular}{|l|c|c|}
\hline & Number of companies & Percentage \\
\hline Full digital annual report & 179 & 59.6 \\
\hline No digital annual report & 48 & 16.0 \\
\hline No website & 31 & 10.3 \\
\hline Website under construction & 2 & 0.8 \\
\hline Failed To access & 3 & 1.0 \\
\hline Delisted & 37 & 12.3 \\
\hline TOTAL & 300 & 100 \\
\hline
\end{tabular}

Arthur Andersen conducted an international survey of the top 350 companies in 2000 and found that 88 per cent were using the Internet to provide information such as annual reports. However, companies in South Africa have increased their use of the Internet as a distribution channel for the publication of annual reports in the past three years from 11 per cent in 1999 to 84 per cent in May 2002.

Results indicate that only 131 (43.6 per cent) South African companies published their annual reports in PDF format (see Table 2). This is low compared to the study by the Financial Accounting Standards Board (FASB) in the USA in 2000, which reported 61 per cent of annual reports in PDF format. Only 58 (19.3 per cent) companies published their annual reports in HTML format, compared to 59 per cent of US companies in the FASB study (2000).

Table 2 Annual reports in PDF format

\begin{tabular}{|l|r|r|r|r|r|r||}
\hline PDF & \multicolumn{2}{|c|}{$\mathbf{2 0 0 1}$} & \multicolumn{2}{c|}{$\mathbf{2 0 0 0}$} & \multicolumn{2}{c|}{1999} \\
\hline & $\begin{array}{c}\text { No of } \\
\text { com- } \\
\text { panies }\end{array}$ & \% & $\begin{array}{c}\text { No of } \\
\text { com- } \\
\text { panies }\end{array}$ & \% & $\begin{array}{c}\text { No of } \\
\text { com- } \\
\text { panies }\end{array}$ & \% \\
\hline Yes & 131 & 43.6 & 91 & 30.3 & 49 & 16.3 \\
\hline No & 48 & 16.0 & 88 & 29.3 & 130 & 43.3 \\
\hline $\begin{array}{l}\text { No digital annual } \\
\text { report }\end{array}$ & 48 & 16.0 & 48 & 16.0 & 48 & 16.0 \\
\hline No website & 31 & 10.3 & 31 & 10.3 & 31 & 10.3 \\
\hline
\end{tabular}


Table 2 continued

\begin{tabular}{|c|c|c|c|c|c|c|}
\hline \multirow[t]{2}{*}{ PDF } & \multicolumn{2}{|c|}{2001} & \multicolumn{2}{|c|}{2000} & \multicolumn{2}{|c|}{1999} \\
\hline & $\begin{array}{c}\text { No of } \\
\text { com- } \\
\text { panies }\end{array}$ & $\%$ & $\begin{array}{c}\text { No of } \\
\text { com- } \\
\text { panies }\end{array}$ & $\%$ & $\begin{array}{c}\text { No of } \\
\text { com- } \\
\text { panies }\end{array}$ & $\%$ \\
\hline $\begin{array}{l}\text { Website under } \\
\text { construction }\end{array}$ & 2 & 0.8 & 2 & 0.8 & 2 & 0.8 \\
\hline Failed to access & 3 & 1.0 & 3 & 1.0 & 3 & 1.0 \\
\hline Delisted & 37 & 12.3 & 37 & 12.3 & 37 & 12.3 \\
\hline TOTAL & 300 & 100 & 300 & 100 & 300 & 100 \\
\hline
\end{tabular}

Only seven companies (2.3 per cent) gave users the option of downloading information into a spreadsheet format. This is significantly lower than the 16 per cent reported in the FASB study of the US economy in 2000.

The study also investigated the relationship between digital annual reports (dependent variable) and company characteristics (independent variable). The two independent variables chosen were profitability and industry type. The two dependent variables chosen were corporate Web presence and digital annual reports. An investigation was carried out to determine whether there was a positive and significant-significant relationship between industry type and the presence of digital annual reports on the corporate website. The companies were classified into the seven JSE sectors. Only three sectors, namely financial (47 companies), industrial (184 companies) and mining resources (35 companies) were chosen, because the number of companies in the other sectors (insurance, non-mining resources, venture capital and real estate) was insignificant.

The Chi-square test was used to test for a relationship between the dependent variables and industrial classification. Table 3 shows the results for industrial classification tested against the dependent variables.

Table 3 Testing against industrial classification

\begin{tabular}{|l|r|r|}
\hline & Digital annual reports & Web presence \\
\hline Chi-square & 6,283 & 1,477 \\
Degrees of freedom & 2 & 2 \\
p (significance) & $0,043^{*}$ & 0,478 \\
\hline
\end{tabular}

*Levels of significance 0.99 per cent at 0.05 (2 tailed test)

It can be concluded that there is a significant relationship between industrial sector and digital annual reports. Of the companies in the industrial sector, 63.6 
per cent had digital annual reports compared to 82.1 per cent in the financial sector and 77.4 per cent in the mining resources sector.

The conclusion can be drawn that there is no significant correlation between companies with a Web presence and the type of industry in which each company operates. Of the companies in the industrial sector, 85.8 per cent had a Web presence compared to 92.3 per cent in the financial sector and 90.3 per cent in the mining resources sector.

The aim of this study was to ascertain whether the companies with a Web presence are more profitable than those without. Net profits in R millions for the top 300 companies as published in the Financial Mail 2001 survey were used.

Profit can be defined as the positive difference that results from selling products and services for more than the cost of producing these goods. Net profit/net income/net earnings can be defined as the sum remaining after all expenses have been met or deducted, or as the difference between total sales and total costs and expenses. Total costs comprise cost of goods sold including depreciation (Downes \& Goodman, 1995).

Table 4 clearly shows that it is the more profitable companies that have a Web presence.

Table 4 Testing of profitability against a corporate web presence using the Mann-Whitney Test

\begin{tabular}{|l|l|r|r|r|r|r|}
\hline & Groups & Mean & $\begin{array}{c}\text { Standard } \\
\text { deviation }\end{array}$ & $\begin{array}{c}\text { Mann- } \\
\text { Whitney U }\end{array}$ & Z & P-value \\
\hline $\begin{array}{l}\text { Net } \\
\text { profit }\end{array}$ & Yo & 105.25 & 260.55 & 2680.500 & -2.841 & $0.004^{* *}$ \\
\hline
\end{tabular}

**Levels of significance 0.99 per cent at 0.01 ( 2 tailed test)

The objective was also to determine whether companies with digital annual reports are more profitable than companies without digital annual reports. 
Table 5 Testing of profitability against availability of digital annual reports using the Mann-Whitney Test

\begin{tabular}{|l|l|r|r|l|l|r|}
\hline & Groups & Mean & $\begin{array}{l}\text { Standard } \\
\text { deviation }\end{array}$ & $\begin{array}{l}\text { Mann- } \\
\text { Whitney U }\end{array}$ & Z & P-value \\
\hline $\begin{array}{l}\text { Annual } \\
\text { report }\end{array}$ & $\begin{array}{l}\text { No } \\
\text { Yes }\end{array}$ & $\begin{array}{r}99,18 \\
525,43\end{array}$ & $\begin{array}{r}227,67 \\
1454,50\end{array}$ & 4866,00 & $-4,244$ & $0,00 * *$ \\
\hline
\end{tabular}

***evels of significance 0,99 per cent at 0,01 ( 2 tailed test)

From the above data in Table $5(\mathrm{p}<0.01)$ it is clearly shown that it is the more profitable companies which have a digital annual report on their corporate websites.

\subsection{Discussion of findings}

During the last three years the use of the Internet by companies in South Africa has shown rapid growth. Traditional paper-based annual reports are becoming increasingly less timely and thus less useful to investors. Increased global competition and a more informed shareholder base are placing pressure on companies to be increasingly proactive and to use the Web to communicate with shareholders. This is evident from the increased use of the Internet for the distribution of annual reports by business entities in South Africa. It is also clear from the results of this study that it is the profitable companies that are employing Internet technology. Companies will have to exploit the full potential of the Internet as a medium to stay competitive or they will be left behind.

Transparency, openness, availability and accessibility of information are beneficial to learning, knowledge and the evolution of both individuals and the business environment. Internet technology is making markets more transparent and companies more open and accountable, resulting in increased shareholder loyalty and commitment. The trend of corporate openness will grow internationally. South African companies will eventually follow the countries that can be classified as early Internet adopters, namely the US, UK and Europe.

With South African companies listing on foreign exchanges and foreign investors looking to emerging markets, there will be increased pressure for South African companies to fall in line with global trends in disseminating information on the Internet. Many companies are not taking full advantage of the Internet as a vehicle for attracting international global investors and capital, or seeking markets beyond their national borders. It is in the interest of South African companies to provide all stakeholders with as much information as possible. Stakeholders increasingly need relevant, up-to-date, well-packaged 
and widely disseminated information when they are researching corporate, strategic and financial issues. The trend of stakeholders using the Internet for research purposes to gather and analyse business information will increase. The biggest benefit of the Internet as a distribution channel is the provision of more information, in a more creative fashion, to more users at a reduced cost. The Internet as a communications medium cannot be ignored, and companies that fail to realise this may experience difficulty in finding investors, suppliers and employees.

Most of the companies in South Africa are at stage two of the development stages of annual reports on the Internet as identified by Hedlin (1999: 73). At this intermediate stage, companies have a Web presence and an electronic version of their annual reports, but are not making use of interactive features. South African companies should take advantage of the unique interactive nature and multimedia features of Internet technology as a medium for maximising global access to corporate data and information transparency. Streaming audio and video, slide presentations, animation and music should be incorporated in annual report presentations. South African companies will have to make an extra effort to present information in a format relevant to the needs of various sets of stakeholders by customising access to and packaging information and data according to stakeholder needs and preferences. Corporate websites should be sticky, engaging and retain users and investors. Corporate home pages are a competitive asset and the prime gateway to any company. The rich sophisticated multimedia environment of text, graphics, images, sound and audio information will be the primary medium for communicating globally with stakeholders in the future.

Company websites are being used more and more by people seeking financial information for making informed investment decisions. This is particularly true in South Africa, where there is no advanced electronic government filing system such as EDGAR (USA) and SEDAR (Canada) available to stakeholders. The primary source of information is company websites.

South Africa needs a website similar to www.carol.co.uk. This could be a gateway or portal for easy location of annual reports on the Web in South Africa. It would provide intelligent links to all South African JSE listed company annual reports on the Internet. This type of service dispenses with the need for search engines to locate annual reports and is free to all users. The service provides HTML links to all the annual reports wherever they are on the Internet. The company sites can be accessed either alphabetically or by sector.

The terminology used when referring to digital annual reports is also problematic. South African companies seem to use the term "annual report" on 
their website when they are actually referring to the "annual financial report". This is not the full or detailed annual report, but just the annual financial information. This could be confusing to stakeholders.

At this stage it is not possible to distribute annual reports on the Internet only. Companies must continue to use traditional means of dissemination, because electronic communication does not reach all investors. There are users that resist electronic formats and that do not have the computer skills, hardware and software to access information. The traditional printed annual report will have to be supplemented with digital annual reports on the Internet. This dual-format situation is likely to change in the future, with the Internet becoming the premier channel for information dissemination and the primary platform for corporate disclosure, supplemented by printed material.

Currently there are no laws or regulations forcing companies to publish annual reports on the Web. There are no rules governing Internet disclosure or digital annual reports in South Africa, although companies are not allowed to release price-sensitive new information on the Internet or distribute it via e-mail without first making an announcement on the JSE news service (SENS). The use of technology is developing faster than regulations at national and international level. The development of the Internet and its use by the business community to distribute financial information is occurring so rapidly that companies, standard setters and regulators have not addressed many fundamental issues. The law treats Web-based annual reports as a supplement to printed reports. This has the result that all company disclosure on the Internet is voluntary. No authorities regulate and monitor this process or the information posted on the Web. The government, auditors, accounting standards generating bodies and the JSE all have a role to play in working toward finding solutions to the current problems and the risks facing companies publishing annual reports on the Web.

The King Report on Corporate Governance for South Africa (King, 2002: 148) also calls for increased disclosure and transparency. It also encourages companies to make use of the Internet for communication stakeholders (King, 2002: 141), but highlights the security risks involved: "given the impact of technology on communication, there will be increased pressure to make information available electronically. While this represents an opportunity to communicate in good time with stakeholders and the broader investment community, an important aspect will be to ensure the security of the data and/or information communicated by electronic means so that its integrity is not compromised through unauthorized means." The King Committee recommends that "companies should make every effort to ensure that information is distributed via a broad range of communication channels, including the internet; having regard for its security and integrity while bearing in mind the need that 
critical financial information reaches all shareholders simultaneously” (King, 2002: 141).

The Promotion of Access to Information Act (No 2 of 2000) has as an objective the promotion of "transparency, accountability, and effective governance of all public and private bodies". Companies will have to incorporate these requirements into their communication with stakeholders (King, 2002: 101).

This study indicates that the number of South African companies with a Web presence is growing. More companies are publishing annual reports on the Web than before. PDF is the most popular format. South African companies should offer users various options in online versions and formats. HTML is ideal for reading and scanning the document online. PDF is ideal for printing and the spreadsheet format for manipulation of data. The user should also be able to choose between online viewing, downloading and viewing offline as well as online ordering of the print copy. Multi-versions of the annual report accommodate users at the high and low ends of the bandwidth spectrum. Different versions of browsers and platforms to access the annual report should also be considered because increasing use is made of wireless devices and cell phones to access and download business information.

The corporate website should also be used as an electronic data archive to store historical corporate information, providing at least five years of historical information. Full annual reports for five years should be in PDF format. Full financials for five years should be available in spreadsheet format for downloading. Other statistical and non-financial data such as sales and employee figures should also be available in spreadsheet format.

It can also be concluded that South African companies are behind the top performing overseas companies in using the Internet as a delivery and communication mechanism to voluntarily disclose information and disseminate digital annual reports.

\section{CONCLUSION}

Although annual reports are perceived as stale and outdated in their current form and pose many problems in hard or soft copy, they remain a very important source of information for decision-makers. The Internet has had a significant influence on the format of the annual report. The format of the annual report will continue to change, as it migrates from hard copy print to electronic digital format. The annual report of the future will be interactive, updated more frequently, have a global audience, disclose more, offer downloading and 
manipulation of data and personalisation and customisation of information. This study indicates that the benefits of digital reports outstrip the disadvantages and that digital reports are the way forward for the future. The issue has changed from whether a company will publish an online annual report, to what form that interactive online annual report will take.

\section{REFERENCES}

$1 \quad$ AIMR see Association for Investment Management and Research.

2 ARTHUR ANDERSEN (2001) "It's raining news: A study of more frequent reporting by large companies”, WWW: http://www.andersen.com/uk. (downloaded 20-1-2002).

3 AIMR (2001) "Educated investor", The Value of the Annual Report, WWW: http://www.aimr.org, (Downloaded 2002-02-24).

4 ASSOCIATION FOR INVESTMENT MANAGEMENT AND RESEARCH (AIMR) (2000) Corporate Disclosure Survey, WWW: http://www.aimr.org. (Downloaded 2002-01-15).

5 CATRAKILIS, H. (1993) "The perceptions of the institutional investor regarding the quality of the annual report”, Unpublished MComm dissertation, University of the Witwatersrand, Johannesburg.

6 CONOSCO (1999) iRelations - Effective Online Investor Relations, WWW: http://www.conosco.com. (Downloaded 2002-03-18).

7 CROSOER, M. (2000) “An investigation into the relationship between the performance and the quality of reporting of large listed companies in South Africa”, Unpublished BCom (Hons) research paper, University of Cape Town, Cape Town.

8 CROWTHER, D. (2000) "Corporate reporting, stakeholders and the Internet: Mapping the new corporate landscape," Urban Studies, 37(10): 1837-48.

9 DEDONATO, J. \& TRAVER, A. (2000) "Internet is changing the face of annual reports,” Business Journal-Portland, 17(33): 39.

10 DOWNES, J. \& GOODMAN, J.E. (1995) Dictionary of Finance and Investment Terms, Barron's: New York.

11 EPSTEIN, M.J. (1991) "Annual reports and shareholders," Corporate Board, 12(69): 10.

12 ERNST \& YOUNG. (2000) "Excellence in financial reporting," The 2001 Survey of Annual Reports by South Africa's Top 100 Companies, WWW: http://www.ey.com/southafrica, (Downloaded 2002-02-14).

13 FASB see Financial Accounting Standards Board.

14 FINANCIAL ACCOUNTING STANDARDS BOARD (2000) "Business Reporting Research Project (BRRP). Electronic distribution of business 
reporting information”, Steering Committee Report Series, WWW: http://www.fasb.org. (Downloaded 2002-01-10).

15 FINANCIAL ACCOUNTING STANDARDS BOARD (2001) "Improving business reporting: Insights into enhancing voluntary disclosures", Steering Committee Report Series, WWW: http://www.fasb.org. (Downloaded 2002-04-24).

16 FINANCIAL MAIL SPECIAL SURVEY (2001) Top Companies. Supplement to the Financial Mail, 29 June 2001.

17 HEDLIN, P. (1999) "The Internet as a vehicle for investor relations: The Swedish case,” European Accounting Review, 8(2): 373-381.

18 ICAEW see Institute of Chartered Accountants

19 INSTITUTE OF CHARTERED ACCOUNTANTS IN ENGLAND AND WALES (2002) The $21^{\text {st }}$ Century Annual Report, WWW: http://www. icaew.co.uk. (Downloaded 2002-03-13).

20 KEENAN, T. (2001) "Jaarverslae ontbloot 'n maatskappy se siel," Finansies \& Tegniek, 26 November: 54.

21 KING, M.E. (2002) King Report on Corporate Governance for South Africa. King Committee on Corporate Governance. Parktown, South Africa, Institute of Directors in Southern Africa.

22 MARSTON, C. \& LEOW, C.Y. (1998) Financial Reporting on the Internet by Leading UK Companies, WWW: http://accounting.rutgers.edu/ SUMMA/SUMMA/corp/papers/marston/marston.html, (Downloaded 2002-04-24).

23 MYBURGH, J.E. (2001) "The extent of voluntary disclosure in corporate reports of South African listed industrial companies”, Unpublished DComm dissertation, University of Pretoria, Pretoria.

24 PUBLIC RELATIONS SOCIETY OF AMERICA (2000) New Survey of Investment Information Sources, WWW: http://www.ir101.com/classroom/ ARcredibilityPRSA.html. (Downloaded 2002-02-13).

25 RAFFOURNIER, B. (1995) "The determinants of voluntary financial disclosure by Swiss listed companies,” European Accounting Review, 4(2): 261-280.

26 RHEIN, J.H.W. (2000) “Annual reports: Numbers in cyberspace," Equities, 48(2): 73.

27 SA firms show low disclosure levels (2002) Business Day, 6 June.

28 SOUTH AFRICA (2000) Promotion of Access to Information Act (No 2 of 2000) Government Printer, Pretoria.

29 SPAUL, B. \& GREEN, G. (1997) "Want to be an information engineer?," Accountancy: International Edition, 119(1246): 46-47.

30 STANTON, P. \& STANTON, J. (2001) Researching Corporate Annual Reports: An Analysis of Perspectives Used, WWW: http://visar.csustan.edu/ papers/contents.htm, (Downloaded 2002-03-10). 
31 SUTCLIFFE, H. (1998) "Sooner, sharper and simpler reporting," Management Accounting, 76(10): 81.

32 XIAO, Z. (1996) Financial Reporting on the Internet, WWW: http://www.cf.ac.uk/carbs/accfin/xiao/baascot.html, (Downloaded 200204-14). 